\title{
AN AGRIANIAN-PAEONIAN CITY NEAR PČINJA, KUMANOVO REGION
}

\begin{abstract}
The first one to reach the thoughts of peoples past who have long since left the path under the golden yellow sunlight is the archaeologist who holds objects shaped in ancient history. History attempts not to manipulate the past, but there are numerous cases that testify to the fact that the analyst-historian either praises the overly insufficient feats of the ruler, or distorts and alleviates the facts of their defeats. This is why archaeological artefacts and immovable archaeological creations offer the most authentic, archaeological truth for the moments in time through which the hearts of ancestors of modern nations beat in every corner of the earth.

Today, for just a moment, we will enter a part of the long-lost world of the Agrianes. We will observe an Agrianian city that flourished in Early Antiquity on the banks of the Pčinja River and disappeared in the whirlwind of the Celtic-Gaelic breakthrough at the beginning of the 3rd century $\mathrm{BC}$.
\end{abstract}

\section{Who were the Agrianes?}

The Agrianes were the northernmost people of the great population of Paeonians. They were the most allies of the Ancient Macedonians, the northernmost guardians of the Early Antique Mediterranean Balkan civilization, the fiercest and most loyal soldiers in the Macedonian army under Alexander III of Macedon, and afterwards as well - in the armies of the Macedonian kings from the second Antigonid dynasty. ${ }^{1}$

In his seventh book, the historian Strabo points out that not only the Strymon River (Struma), but the river Axius (Vardar) as well, spring from the area where the Agrianes lived ${ }^{2}$ meaning from Vrutok in Gostivar, through the Polog and Skopje regions.

${ }^{1}$ N. G. L.Hammond amp; F. W. Walbank, A History of Macedonia, Oxford 1988, $32,35,38-40,44,46,48,50,53,61,89,105,468,515,529,542,617$; V. Sokolovska MAA 11, 19, with the cited literature in footnotes 56-57.

${ }^{2}$ Str VII. frg. 36, according to V. Sokolovska, Pajonskoto pleme Agrijani $i$ vrskite so Damastion, Macedonia acta archaeologica, br. 11, Skopje 1990, 18, f.n. 47. 
During the Archaic, Classical and Hellenistic periods, the Agrianes inhabited a large territory which covers the present-day regions of Polog, the Skopje-Kumanovo region, Kriva Palanka, Kosovo, Južna (South) Morava, the Sofiisko Pole (Sofia Field) and the Kyustendil region. ${ }^{3}$

Upon the return from his campaign, in 335 BC, Alexander III of Macedon, started from the river Istar (Danube), passed through the countries of the Agrianes and the Paeonians, and then along the valley of the river Erigon (Crna Reka), reaching the city of Pelium, south of the Lychnidus Lake (Lake Ohrid). ${ }^{4}$

Experts are trying to define the route of his march, but the difficulties arise from the drastically narrowed description by Arrian, who provides no account of almost any details apart from the position of the Agrianian king Langarus. Namely, the Agrianian king Langarus, at that moment happened to be right there with his protectors, the best and most heavily armed soldiers that there were. When he learned that Alexander was inquiring about the Autariatae, who they were and how many, he noted that they were not worth mentioning, being the least

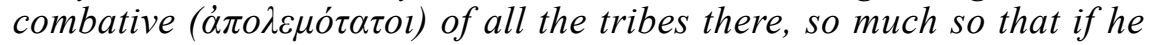
himself had entered their country, they would care more of their own affairs. ${ }^{5}$

Fanula Papazoglu believed that Alexander of Macedon was returning through Sofia, Kyustendil and Stobi. Similarly, Nicholas Hammond

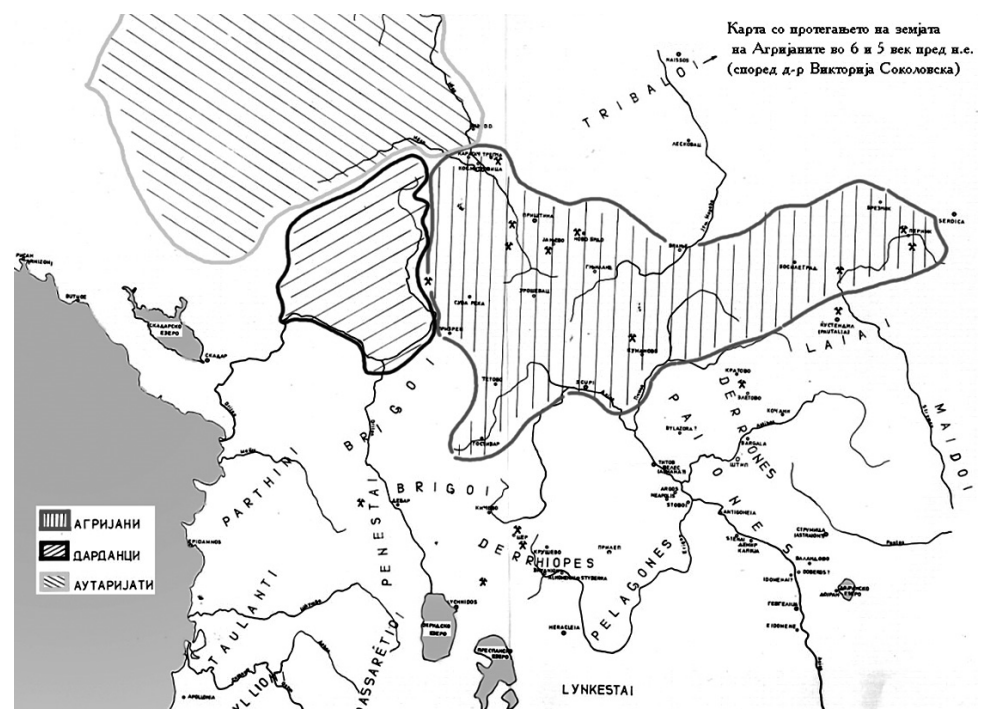

fig. 1 Map of the extension of the kingdom of Agrianes (acc. to V. Sokolovska)

\footnotetext{
${ }^{3}$ V. Sokolovska, o.c., 18-20.

${ }^{4}$ Arr. I. 4-5: Arijan, Aleksandrova Anabasa, Skopje 2000, prevod na makedonski Margarita Buzalkova-Aleksova.

${ }^{5}$ Arr. I. 5.
} 
suggested the route Sofia-Kyustendil, then either through the Skopje region or through Štip toward Stobi near the flow of Erigon (Crna Reka) into Vardar. ${ }^{6}$ This would mean that Alexander and his army undoubtedly passed through the regions of Kriva Palanka and Kumanovo, probably even close to the Agrianian city at the site of Gradište near Pčinja.

\section{Where was the capital of the Agrianian king Langarus?}

The issue regarding the spread of the ancient Agrianes was most thoroughly examined by Viktorija Sokolovska. From her study regarding the Paeonian tribe Agrianes and the relations with Damastion, ${ }^{7}$ we learn that the Agrianian territory in the Archaic and Classical periods contained eight civilizational cores: the Kosovo region, South Morava, Polog, the Skopje region, Kumanovo, the region of Kriva Palanka, the Sofiisko Pole and Kyustendil. In this context, one wonders if this state is in any way associated with Arian's data, according to whom the Agrianian King Langarus was accompanied by his strongest armies, which he gathered from the previously mentioned eight Agrianian regions.

The larger Agrianian cities explored by archaeologists were located on the sites: Kale near the village of Krševica, close to Vranje, Oraovica near Preševo, Gradište near Brazda, Isar near Studeničani, and in the east, the city at the site of Krakra near Pernik.

Considering the high civilization qualities of the fortification perimeter around the aforementioned Agrianian cities, the local production of movable objects, and especially the high quality luxury imports from the southern Aegean manufacturing centres, the cities of Krševica (Vranje), Brazda and Studeničani in Skopje can clearly be distinguished. ${ }^{8}$

The issue of King Langarus's capital, however, remains open for the time being, though some Early Antique cities have already indicated its ubication - the cities near Krševica, Brazda, Studeničani and Pernik. The latest archaeological studies regarding these sites provide an opportunity for a more extensive elaboration of this issue, which, for the time being, is outside the contents of this article.

The mighty kingdom of Paeonia, with the royal dynasties of Agis, Lycceius, Patraus, Audoleon, Leon and Dropion was formed to the south of the kingdom of the Agrianes, in the Sredno Povardarje (MidVardar) region and the river Astibus (Bregalnica) in the period of Early Antiquity. ${ }^{9}$

${ }^{6}$ F. Papazoglu, Srednjobalkanska plemena u predrimsko doba, Sarajevo 1969, 79; N. G. L. Hammond; F. W. Walbank, o.c., 40.

${ }^{7}$ V. Sokolovska, o.c., 9-34.

${ }^{8}$ V. Sokolovska, o.c., 19-20; Mikulčić, Staro Skopje so okolnite tvrdini, Skopje 1982.

${ }^{9}$ E. Petrova, Pajonija vo II i I milenium pred n.e., Makedonska civilizacija; Muzej na Makedonija, Skopje 1999, 1-255; E. Pavlovska, Monetite na Pajonija, Narodna banka na Republika Makedonija, Skopje 2008, 1-104. 

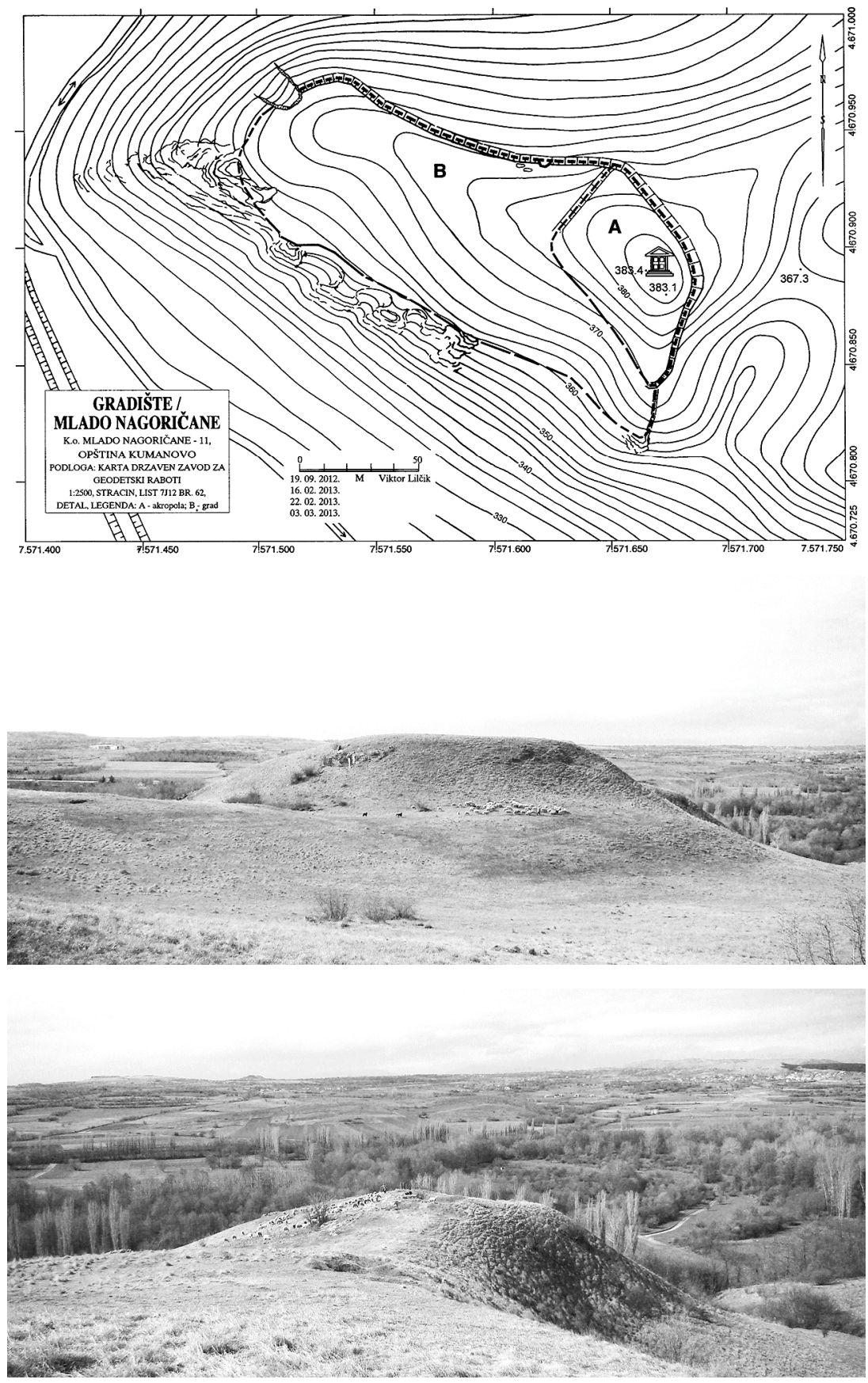

fig. 2-4: Gradište, village of Mlado Nagoričane, planimetry of the Agrianian town; view of the acropolis from the east; view of the lower part of the city, from the acropolis. 
These Paeonian kings minted their own silver coins, and ruled from a capital not yet identified, but to be determined with future archaeological research, undoubtedly in one of their larger cities: Bylazora at Gradište, near the village of Knežje, Astibus at Isar, near Stip or perhaps Audaristus at Gradište, near the village of Drenovo.

Historical and archaeological data speak of the great moments of the expansion of the Agrianian kingdom in the $6^{\text {th }}, 5^{\text {th }}$ and $4^{\text {th }}$ centuries $\mathrm{BC} .^{10}$

By the end of the $4^{\text {th }}$ century BC, the Paeonian community of the Agrianes, which probably remained without a ruler, was annexed by Audoleon, the king of Paeonia, (ca. 315-285/4 BC). ${ }^{11}$ Afterward, in the tumultuous beginnings of the $3^{\text {rd }}$ century $\mathrm{BC}$, due to the impact under the invasion of the Celts, and probably more so under the invasion of the Dardanians, the Agrianes lost the existential supremacy in the main territories of Kosovo, Polog and the Skopje-Kumanovo region. ${ }^{12}$ Namely, Agatharchides of Cnidus states that among the Dardanians there were people who owned one thousand or more slaves. ${ }^{13}$

F. Papazoglu attempts to explain this unusual phenomenon in detail, but without considering that it is difficult to expect a galloping increase in the birth of the Dardanians in such a short time as to inhabit the large newly conquered terriotories. ${ }^{14}$

The Dardanians set off from their home country west of the valley of the Bel (White) Drim river at the beginning of the $3^{\text {rd }}$ century BC, by no means taking advantage of the demographic draining of a large number of young Agrianes who left for Alexander III's expedition to Asia and the Celtic invasion of the Balkans in 280/279 BC. They conquered the regions of Kosovo, Južna (South) Morava, possibly Polog and the regions of Skopje and Kumanovo.

In this context, I believe that the information provided by Agatharchides of Cnidus, according to whom some Dardanians owned one thousand or more slaves (douloi), refers, in fact, to the autochthonous Agrianes, who were of better use to the Dardanians alive and obedient in their conquests with the Paeonian and Macedonian civilization centres, as it is difficult to believe that a relatively small tribe, with an insufficiently defined Iron Age culture, bearing in mind their territory of approximately $80 / 90 \times 60 / 70 \mathrm{~km}$ i.e. a maximum of $6300 \mathrm{~km}^{2},{ }^{15}$ to be able to allow for such internal class differentiation.

\footnotetext{
${ }^{10} \mathrm{~V}$. Sokolovska o.c., with cited literature.

${ }^{11}$ V. Sokolovska o.c., 19.

${ }^{12}$ V. Sokolovska o.c., 21.

${ }^{13}$ F. Papazoglu, 1969, 368, f.n. 157.

${ }^{14}$ F. Papazoglu, o.c., 368-372.
}

${ }^{15}$ See the Map no. 1 at V. Sokolovska, o.c., map no. 1 after page 16 . Otherwise F. Papazoglu, o.c., 372, points out that the territory in which the Dardanians lived extended at $25-30.000 \mathrm{~km}^{2}$, whereby she probably thinks of the maximum Dardanian stretching, along with the newly conquered territories. 

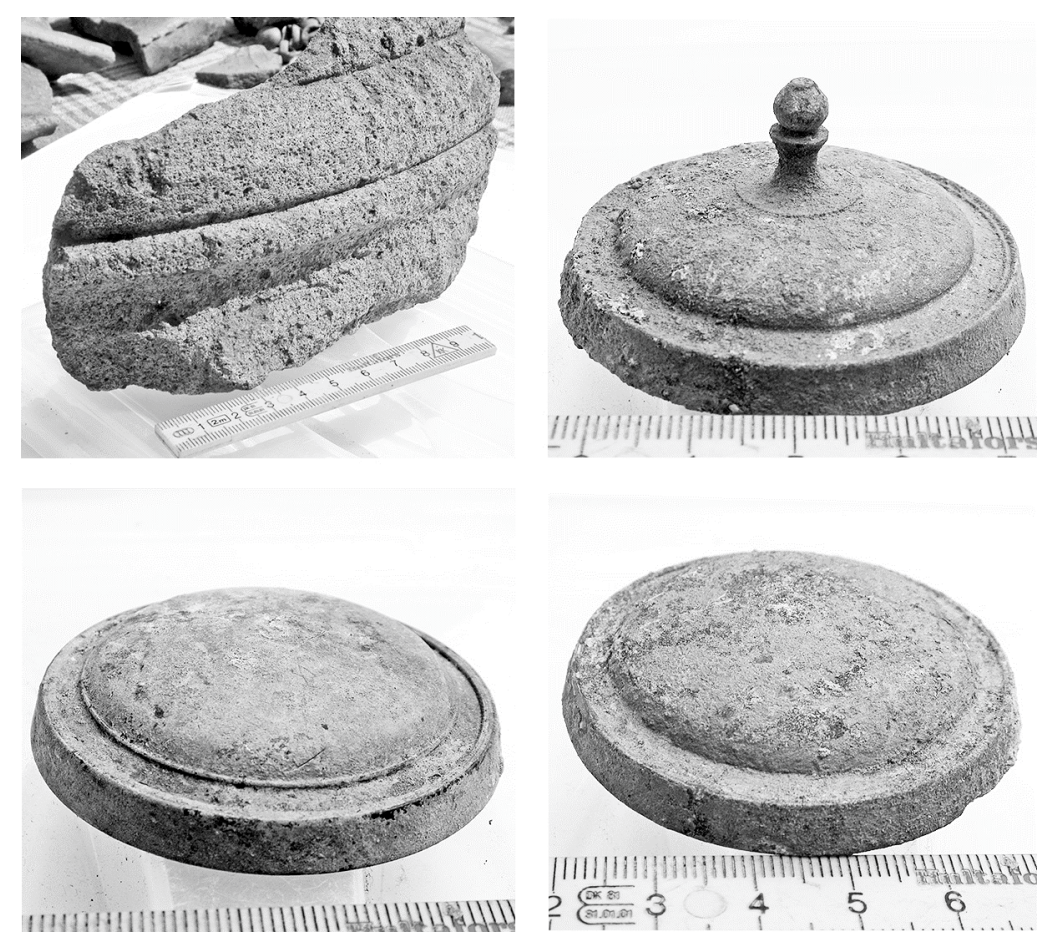

fig. 5-8: A part of the early antique base, probably from an temple in the acropolis; bronze application 1 in the form of a shield (omphalos) for the door of the city temple; bronze application 2 in the form of a shield (omphalos) for the door of the city temple; bronze application 3 in the form of a shield (omphalos) for the door of the city temple.

Among the early Agrianian settlements in the Kumanovo region, several cities and fortresses were more prominent than others. Some of them were located at the archaeological sites of Velja Glava, village of Rugjince, Lipec, village of Murgaš, Gradiški Vrh, Gradište village, Gradište, Pelince village, Gradište between the villages of Mlado Nagoričani and Makreš Kostoperska Karpa / Žegligovski Kamen near Mlado Nagoričani and other smaller fortified settlements.

The Agrianian culture in Kumanovo was especially revived in the Iron Age, with the formation of small and large fortified settlements, some along the ancient roads beside the valleys of rivers, such as Pčinja (Pelince and Mlado Nagoričani), or on significant crossroads, such as the fortified settlement Kaljište - Spomen Kosturnica near Kumanovo, but also on separate, higher hilly plateaus with wide views (Kostoperska Karpa near Mlado Nagoričani, Gradište, Murgaš and Velja Glava near Rugjince).

However, a noticeable occurrence in the classical period is that the civilizational supremacy is established by the cities near Pčinja. In 
this sense, the town of Gradište in Mlado Nagorichani is especially highlighted.

The first reference of the old city of Pčinja in expert literature, though with a non-expert description, is accounted for by Jovan Hadži Vasiljević. ${ }^{16}$ He says: Kaljište in the village of Vojnik; on the boundary of the villages of Vojnik and Strnovec there are remains of a fortress. According to the tales of the surrounding inhabitants, this was an area of barracks and military camps in the old days. Many would like to believe that the king-tsar Stefan sat here and performed military exercise with the army. Many interpret the name of the village Vojnik ("soldier") by means of this reference.

Zoran Georgiev, MA (archaeol.), is the first major researcher of this archaeological site, who recorded the city's planimetry, described the landscape and the immovable archaeological finds, documented and interpreted an impressive fund of movable archaeological finds, primarily pottery of utilitarian and representative nature from local production, as well as imported. He was the first to define the chronology of the cultural horizons of this city, as early as the Early Bronze Age, the Iron Age, the Classical period, and the Early Hellenistic period. ${ }^{17}$

The research that we carried out at this site was part of the project titled Archaeological Topography of the Old Cities and Fortresses in the Republic of Macedonia, at the Faculty of Philosophy in Skopje, in partnership with the NGO Centre for Archaeological Research - Skopje in September 2012, as well as February and March of 2013. ${ }^{18}$

This research mainly confirmed the findings and conclusions of $Z$. Georgiev. Nevertheless, we managed to discover archaeological finds that put an emphasis on the urban character of Gradište from the Classical period and the Early Hellenistic period.

The site, according to the cadastral register for Stracin $7 \mathrm{~J}$ 12, no. 62, CM Mlado Nagoričane - 11, though being located on the left bank of Pčinja, opposite the village, belongs entirely to the area, i.e. the cadastral municipality of Mlado Nagoričane, and not the village of Makreš, which is located on the riverbank of the nearby river Petrošnica.

The archaeological site of Gradište is located 4.4 km east of Kostoperska Karpa (Žegligovski Kamen), i.e. from the central part of Mlado Nagoričani, and $1.9 \mathrm{~km}$ north of the bridge over the Pčinja River on the Kumanovo-Kriva Palanka highway. It is a low hill, positioned right next to the left bank of the Pčinja River. It has an elongated shape in a west-east s/e direction. The highest elevation is in the eastern part of the

${ }^{16}$ J. H. Vasiljević, Kumanovska oblast, Beograd 1909, 414.

17 Z. Georgiev, Tri predrimski naselbi kraj Pčinja, Godišen Zbornik na Filozofskiot fakultet vo Skopje, br. 17-18, Skopje 1990-1991, Gradište - Makreš, 9497, plan 2, figs. (plates with illustrations and technical drawings) 4-6.

18 The field surveys were carried by Stojan Stojkov, Velko Kjokjorovski, Jelena Manevska Lilčić, Olja Stojkova and Ana Kjokjorovska. We warmly thank them for the cooperation during the research expeditions on the site. 
acropolis, $383.4 \mathrm{~m}$ above sea level. The level of the river is $320 \mathrm{me}-$ ters, which means the difference is exactly 63.4 meters. The lowest elevation of the western point of the perimetral defensive wall, above the river, is approximately 360 meters, whereas its height above the river level is 40 meters.

The highest plateau on the hill on the eastern side was particularly fortified and represented the acropolis. It was of an almost trapezoidal shape with a central oval plateau and a total area of about 0.35 ha. It measured about $75 / 65 \times 58$ meters. The temple of the city's deity was probably erected on the previously mentioned dominant plateau measuring about $50 \times 30$ meters. Very few of its parts were excavated. Part of a column base, rolled downwards, was registered on the southern slope. It represented a fragment of the base composed of reddish volcanic andesite, bearing a torus and trochilos profile. There is no plinth, and it is unclear whether there is another trochilos above the torus and a second upper torus. At the very northern edge of the acropolis we discovered three small bronze shields - omphaloi, which were applied as a decoration on the main gate of the temple. The central sections of both of them are slightly protruding flat, while at the centre of the third there is a short protruding point.

\section{Description of the city area west of the acropolis}

The remaining area of the city spreads over the elongated plateau to the south, and especially to the west. The ground curves towards the south and slightly towards the west. The total size of the city is 200 $\mathrm{x} 100 / 70 \mathrm{~m}$ with a surface of 1.4 hectares. The line of the defensive wall is visible along the north side where it appears in the form of a sharp edge devastated in several spots due to recent trenches by military units, which have been recorded in more detail in the previously mentioned work by Z. Georgiev. The defensive wall on the south side was almost completely devastated due to the erosive activity that took place over a period of two millennia.

The greatest number of archaeological finds at the site are fragments and parts of pottery. Few Bronze Age fragments have been registered. There is a greater amount of pottery finds from the Iron Age, and forms of the Archaic period can be recognized, such as early forms of kantharoi, as well as flat roof tegulae of the Laconic type, painted in reddish-brown.

Pottery from the Classical period is also numerous, represented by easily recognizable forms of amphorae, kantharoi, scyphoi, rounded edge bowls with a ring base, a column-krater, hydrias, as well a variety of pots. The grey, so-called Paeonic ceramics, is represented by a modest amount of items. The excavated part of a high quality pyxis, adorned with ornaments, strips and dots of thick black glaze, is undoubtedly an import from the south, perhaps Corinth or Athens. 

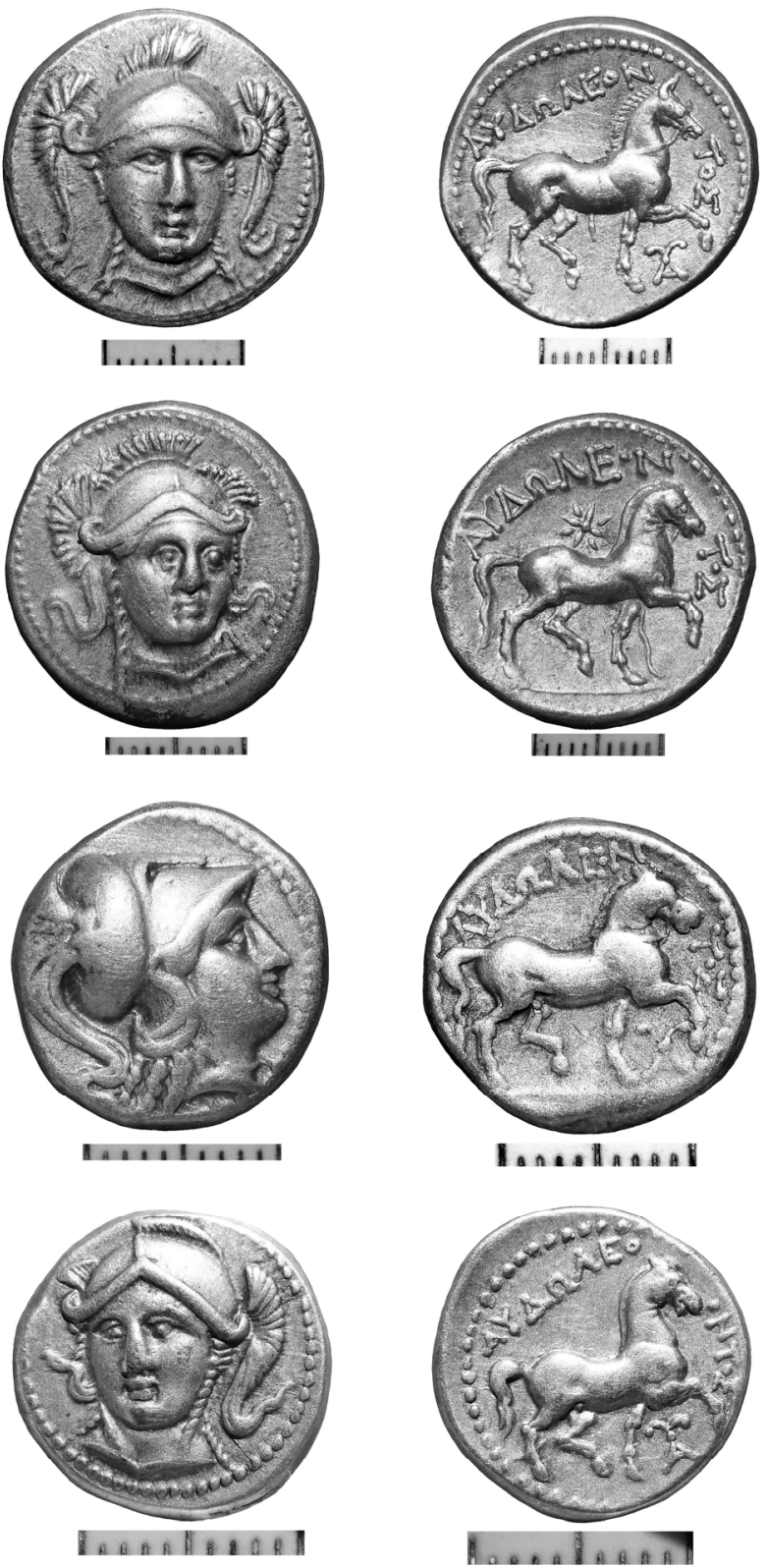

Silver tetradrahmae (9-10), a didrachm (11) and a drachma (12) of Paeonian King Audoleon

Metal objects have also been recorded. Among the registered items were 14 bronze, so-called Iron Age, semi-spherical buttons, as well as a star decorative application, pieces of strip bracelets, two bronze objects of unfamiliar purpose, perhaps a type of jewellery, a part of a handle of 
a small situla, two larger (124.00 g and $100.93 \mathrm{~g})$ and four smaller $(25.28 \mathrm{~g}, 25.17 \mathrm{~g}, 18.55 \mathrm{~g}$ and $16.40 \mathrm{~g})$ lead-shaped weights in the form of tiles, more amorphous lead pieces, as well as strip lead segments used for attaching broken pottery for storing grains. Other excavated items include segments of baked clay plaster with marks of cane reeds, used as building material for houses of the prehistoric, protohistoric and Early Antique inhabitants of Gradište.

The only items from a latter period are two pyramidal ceramic weights used for manufacturing of fabrics, as well as the fragment of a plate of the type terra sigillata, which serve as testimonies for the continuation of existence in the city at a later time in history.

However, the small hoard of 13 silver coins of the Paeonian king Audoleon draws special attention.

Z. Georgiev had registered a silver drachma of Audoleon at Gradište. He noticed the powerful erosion which deteriorated, stretched and devastated the cultural horizons toward the southern slope as early as 1990. In fact, the discovery of the old residential buildings to the level of their floors was due to the existence of erosion, which I believe also lead to the discovery of the previously mentioned hoard of coins. The hoard was discovered at about twenty meters to the southwest, under the acropolis.

This hoard, in fact, as well as the drachma of Audoleon mentioned by Z. Georgiev, confirms the assumption of V. Sokolovska, ${ }^{19}$ that the Paeonian king Audoleon annexed the territory of the Agrianes to Paeonia.

This conclusion is further confirmed by means of the discovery of a silver drachma of Audoleon within the remains of the Agrianian city at the archaeological site of Isar-Kale near the Skopje village of Studeničani. ${ }^{20}$

The hoard at Gradište, Mlado Nagoričani, consists of two tetradrachms, one didrachm and 10 drachmas - all issued by the Paeonian king Audoleon. ${ }^{21}$ The image of the goddess Athens in a dotted circle pattern is depicted on the obverse of all coins. The image of Athens is presented in profile, with a raised Corinthian helmet on the head only on the didrachm, whereas on the other coins the face of the goddess is presented facing front (en face). On the reverse, all coins have a figure of a Paeoian horse in a dotted circle pattern, trotting right. The horse is bridled and the rope usually freely hangs downward. Only one tetradrachm depicts a star of eight rays above the horse. This coin, in particular,

${ }^{19}$ V. Sokolovska 1990, 19.

${ }^{20}$ N. Šeldarov, Makedonija i Pajonija, Kolekcija Šeldarov, Skopje 2003, 148149 , br. 774 .

${ }^{21}$ The weights of coins are: Tetradrachms No 1: 12.56 grams; No. 2: 12.58 grams; didrachma No 3: 6.18 grams; drachmas, No. 4: 3.01 grams; No. 5: 2.98 grams; No. 6: 3.01 grams; No. 7: 2.90 grams; No. 8: 2.99 grams; No. 9: 3.02 grams; No. 10: 3.00 grams; No. 11: 3.07 grams; No. 12: 3.11 grams and No. 13: 3.07 grams. 
does one not depict the monogram $\mathrm{AU}$, whereas the name of the king $\mathrm{AY} \triangle \Omega \Lambda \mathrm{EONTO} \Sigma$ can be observed on all other coins, without the title 'king' (BA $\Sigma \mathrm{I} \Lambda \mathrm{E} \Omega \Sigma)$.
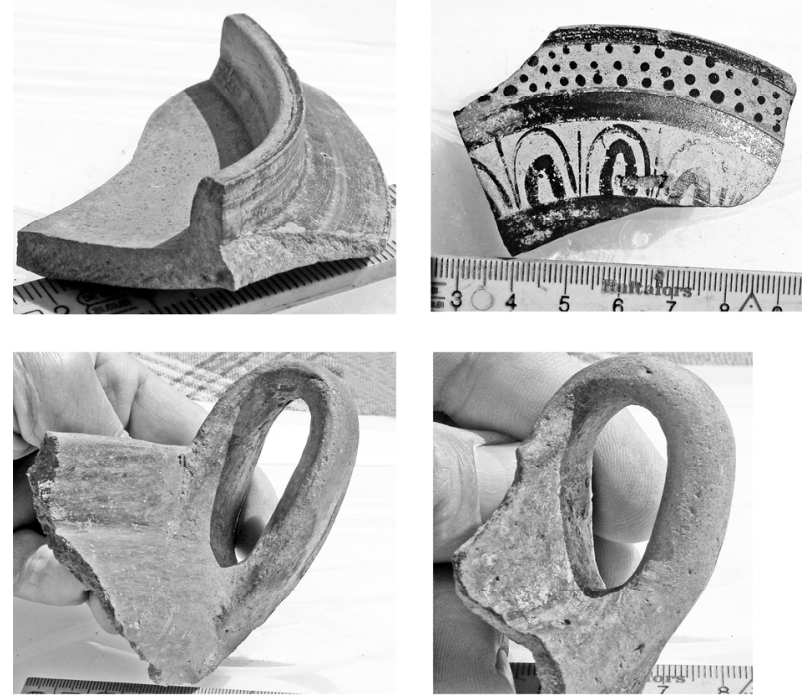

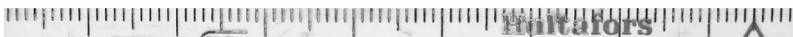

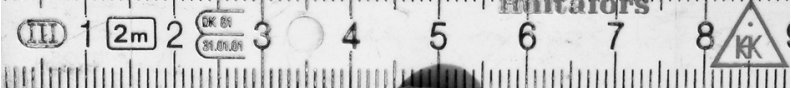

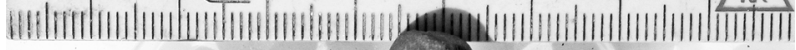
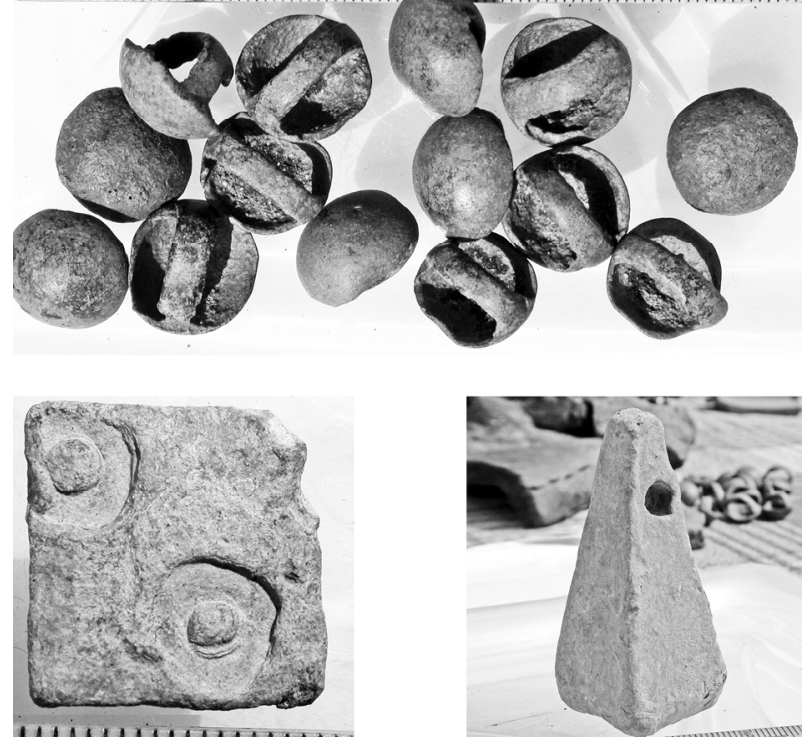

fig. 13-18: Parts of an imported pixis; parts of a cantharos from the archaic period; bronze buttons; lead-type weight in the shape of a small plate, early antiquity; lead-type weight in the shape of a pyramid, early antiquity. 
As it is well-known, in the period following the death of Alexander of Macedon, i.e. about 306/5 BC, Audoleon proclaimed himself king, by example of the diadochoi. ${ }^{22}$ In $285 / 4 \mathrm{BC}$, he received the title 'honorary citizen' by the city of Athens for supplying the Athenians with grain at the time of the siege of the city by Demetrius I Poliorcetes.

Regarding the period of depositing and concealing the hoard, I believe it was, no doubt, hidden as a result of the invasion of the Celts in $280 \mathrm{BC}$. I assume that the Celtic invasion was precisely the reason that life was temporarily subdued in the town of Gradište near Mlado Nagoričani. I would stress temporarily, since a fragment of a quality made bowl of the so-called Samos type, from a latter, Hellenistic/Roman period was discovered during the surface surveys, as if life came to a halt during the $3^{\text {rd }}$ and $2^{\text {nd }}$ centuries $\mathrm{BC}$, and then sometime during the $1^{\text {st }}$ century $\mathrm{BC}$, the ruins of the town near Pčinja were resettled once again.

Consequently, we can assume that life at Gradište appeared in the Bronze Age. We do not know if there was continuity to the Iron Age. The local community suddenly increased and formed a city that flourished in the Late Iron Age / Archaic and Classical periods, until the beginning of the $3^{\text {rd }}$ century BC. I would, however, emphasize that our research was superficial. I am confident that many of the issues that emerged can be resolved by means of conducting systematic archaeological excavations of the extraordinarily abundant archaeological and cultural treasury Gradište, near the village of Mlado Nagoričani in the region of Kumanovo. 